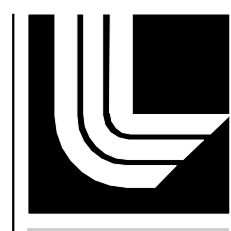

LAWRENCE LIVERMORE NATIONAL LABORATORY
Evaluation of Cavity Collapse and Surface Crater Formation at the Salut Underground Nuclear Test in U20ak, Nevada Nuclear Test Site, and the Impact of Stability of the Ground Surface

Gayle A. Pawloski

March 2012 


\section{Evaluation of Cavity Collapse and Surface Crater Formation at the Salut Underground Nuclear Test in U20ak, Nevada Nuclear Test Site, and Impact of Stability of the Ground Surface}

Gayle A. Pawloski

March 29, 2012 


\section{DISCLAIMER}

This document was prepared as an account of work sponsored by an agency of the United States government. Neither the United States government nor Lawrence Livermore National Security, LLC, nor any of their employees makes any warranty, expressed or implied, or assumes any legal liability or responsibility for the accuracy, completeness, or usefulness of any information, apparatus, product, or process disclosed, or represents that its use would not infringe privately owned rights. Reference herein to any specific commercial product, process, or service by trade name, trademark, manufacturer, or otherwise does not necessarily constitute or imply its endorsement, recommendation, or favoring by the United States government or Lawrence Livermore National Security, LLC. The views and opinions of authors expressed herein do not necessarily state or reflect those of the United States government or Lawrence Livermore National Security, LLC, and shall not be used for advertising or product endorsement purposes.

This work performed under the auspices of the U.S. Department of Energy by Lawrence Livermore National Laboratory under Contract DE-AC52-07NA27344. 


\section{Table of Contents}

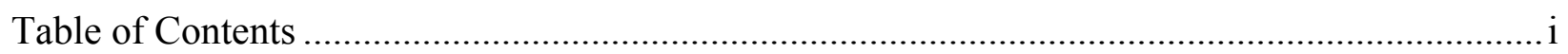

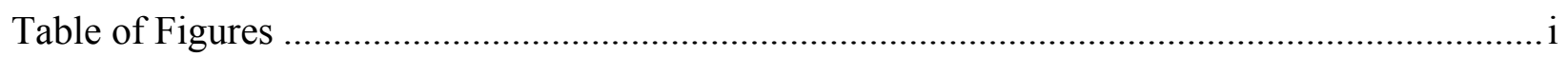

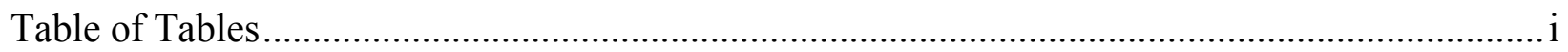

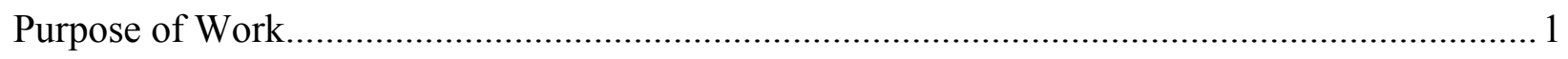

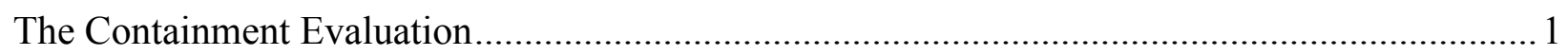

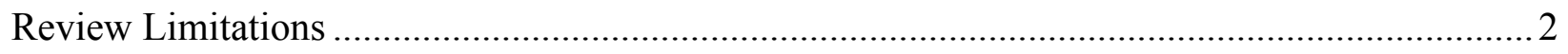

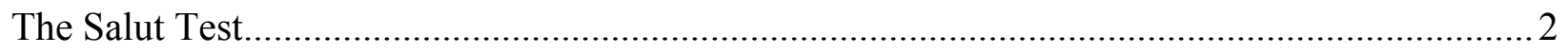

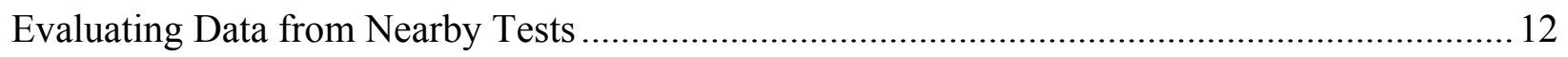

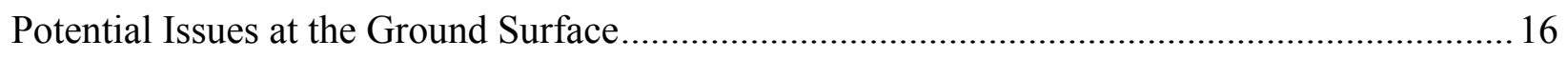

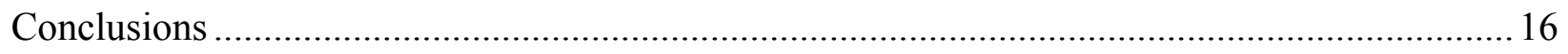

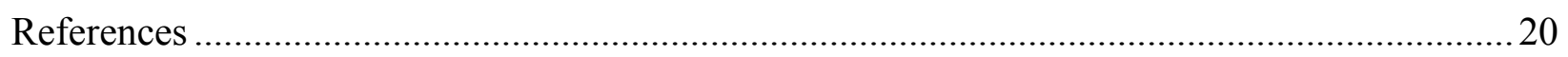

\section{Table of Figures}

Figure 1. Locations of tests in Areas 19 and 20 at Pahute Mesa, NNSS

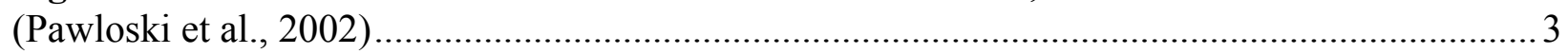

Figure 2. Locations of tests discussed in this report (based on a surface effects map from Grasso, 2003) ................................................................................................. 3

Figure 3. Location of the Area 20 Caldera between the West Purse and West Boxcar faults on Pahute Mesa, NNSS (figure extracted from Bechtel Nevada, 2002) .............................. 5

Figure 4. West-east and southeast-north cross sections of the U20ak site (Pawloski, 1985) ....... 6

Figure 5. Surface effects map of Salut in U20ak (Grasso, 2003)............................................... 9

Figure 6. Surface effects from tests located near Salut in U20ak: Delamar in U20at, Tenabo in U20bb, Knickerbocker in U20d, Tafi in U20ae, Goldstone in U20ao, Benham in U20c, Darwin in U20aw, Egmont in U20al, Hornitos in U20bc, and Fontina in U20f. Chateaugay in U20t did not produce any surface effects

Figure 7. Schematic correlating stratigraphy and lithology for the 12 tests near Salut in U20ak

\section{Table of Tables}

Table 1. Selected information for tests located near Salut in U20ak .......................................... 4

Table 2. Selected collapse information for tests near Salut in U20ak .......................................... 18

Table 3. Selected release information for tests near Salut in U20ak ............................................ 19 


\section{Purpose of Work}

At the request of Jerry Sweeney, the LLNL Containment Program performed a review of nuclear test-related data for the Salut underground nuclear test in U20ak to assist in evaluating this legacy site as a test bed for application technologies for use in On-Site Inspections (OSI) under the Comprehensive Nuclear Test Ban Treaty. Review of the Salut site is complicated because the test experienced a subsurface, rather than surface, collapse. Of particular interest is the stability of the ground surface above the Salut detonation point. Proposed methods for on-site verification include radiological signatures, artifacts from nuclear testing activities, and imaging to identify alteration to the subsurface hydrogeologogy due to the nuclear detonation. Sweeney's proposal requires physical access at or near the ground surface of specific underground nuclear test locations at the Nevada Nuclear Test Site (NNSS, formerly the Nevada Test Site), and focuses on possible activities such as visual observation, multispectral measurements, and shallow, and deep geophysical surveys.

\section{The Containment Evaluation}

The Containment Program utilized subject matter experts who participated in weapons testing activities to perform this evaluation, and focused on the pre-test hydrogeologic setting and the effects of the nuclear explosion on that setting, commonly called containment phenomenology. Information used included drilling and hole construction, emplacement and stemming, timing and sequence of the selected test and nearby tests, geology, yield, depth of burial, collapse times, surface crater sizes, cavity and crater volume estimates, ground motion, and radiological release information. Both classified and unclassified data were reviewed. Various amounts of information are available for the tests included in this review, depending on the age and the associated activities that took place when the test occurred. Lack of data can hamper evaluations and introduce uncertaitny. No attempt has been made to address this uncertainty.

The pre-test containment evaluation requires definition of test specifics, characterization of the geologic setting, and prediction of the shock waves from the explosion and interactions with the geologic layers. Because there are many variables related to the phenomenology and uncertainty is unquantified, common practice included comparison of many aspects of a proposed test to past experience; we expect this would be standard protocol in the future also. Guidelines assisting containment evaluation were developed over time, and Cliff Olsen documented general rules of thumb for site selection and containment evaluation (Olsen, 1993). These rules of thumb are derived from years of experience, and are based on data from successful and unsuccessful containment, statistical analysis of data, and pre- and post-test hydrodynamic modeling.

Sweeney's work proposal includes the possibility of performing work at the ground surface above a cavity and chimney that did not collapse to the ground surface; i.e., the Salut test developed a subsurface collapse. Containment rules of thumb related to collapse were helpful in the evaluation of ground stability near the Salut test. One rule relates depth of burial (also called the working point or WP) and yield (regardless of subsurface geology), where a dividing line between surface crater formation and subsurface collapse on Pahute Mesa is at a scale depth of burial (SDOB) of $125 \mathrm{~m} / \mathrm{kt}^{1 / 3}$. More specifically, for tests at Pahute Mesa, collapse to the surface occured with SDOBs less that $118 \mathrm{~m} / \mathrm{kt}^{1 / 3}$, while subsurface collapse occurred with SDOBs 


\section{Evaluation of Cavity Collapse and Surface Crater Formationat the Salut Test in U20ak}

greater than $132 \mathrm{~m} / \mathrm{kt}^{1 / 3}$. A transition zone exists between these values and is dependent on the site-specific setting. Alternating layers of stronger and weaker volcanic deposits influence the height and rate of collapse at Pahute Mesa. The presence of relatively unconsolidated alluvium, found in Yucca Flat and Frenchman Flat basins but present only as a thin veneer at Pahute Mesa, also influences collapse. Another Containment rule of thumb generalizes that chimney height is $5.5+/-2.0$ cavity radii (Rc). Chimney collapse is the upward propogation of the cavity void volume as a result of the cavity material being unable to support itself. Strong layers can terminate collapse, leaving a void below, or collapse may terminate if bulking of the collapsed material fills the void space.

\section{Review Limitations}

1. By request, the review was limited to utilizing unclassified data. The specific yield of the Salut test is not announced. The report United States Nuclear Tests July 1945 through September 1992 (USDOE, 2000) identifies yields for US nuclear tests. The Salut test yield is anounced as 20 to $150 \mathrm{kt}$. Classification guidance does not permit associating other yields for a given test. Agreement with the Department of Energy (DOE)/National Nuclear Security Administration (NNSA) Nevada Site Office (NSO) Classification Office permits using the maximum of the announced yield range. While this is insightful, utilizing the larger yield gives a larger cavity radius, and this can skew interpretations. Clarifying discussion is not permitted in an unclassified environment.

2. Salut did not collapse to the ground surface. There is limited data to infer how high the collapse proceeded soon after detonation. This is complicated by using the maximum of the announced yield range to calculate a cavity radius and attempt to apply scaled values. Selected other tests near Salut with announced yield ranges are also affected by this. Using maximum yields and scaled values introduces uncertainty, and no expressions of correlation are discussed.

While we consider the impact of ground motion from subsequent tests on surface stability above uncollapsed cavity-chimney systems, we do not consider later erosional effects that may modify collapse craters over time or impacts from recent tectonic movements. We also do not address possible radiation dangers that may currently be present. LLNL does not make decisions concerning safety issues related to activities near a potential (uncollapsed) surface crater area. We rely on Nevada National Security Technologics, LLC (NSTec) and the DOE/NNSA/NSO to make decisions concerning safety issues related to activities near potential and actual crater areas.

\section{The Salut Test}

Salut was one of 82 underground nuclear tests at Pahute Mesa. The LLNL-sponsored Salut test was detonated in U20ak on June 12, 1985. Salut, with an announced yield of 20-150 kt (USDOE, 2000), was detonated in rhyolitic lava at a working point of $608 \mathrm{~m}$ below the surface.

Emplacement hole U20ak is located in west central Area 20 on Pahute Mesa, between the West Purse Fault to the west and the West Boxcar Fault to the east (Figures 1 and 2).

As shown in Figure 2, U20ak is located in a roughly west-east line of five closely located tests, including Delamar in U20at, Tenabo in U20bb, Salut in U20ak, Chateaugay in U20t, and 


\section{Evaluation of Cavity Collapse and Surface Crater Formationat the Salut Test in U20ak}

Knickerbocker in U20d. Another group of tests is located just north of this and includes Darwin in U20aq, Egmont in U20al, Hornitos in U20bc, and Fontina in U20f. Tafi in U20ae is located between the two groups of tests, and Goldstone in U20ao and Benham in U20c are located to the south. Table 1 summarizes selected information for these tests.

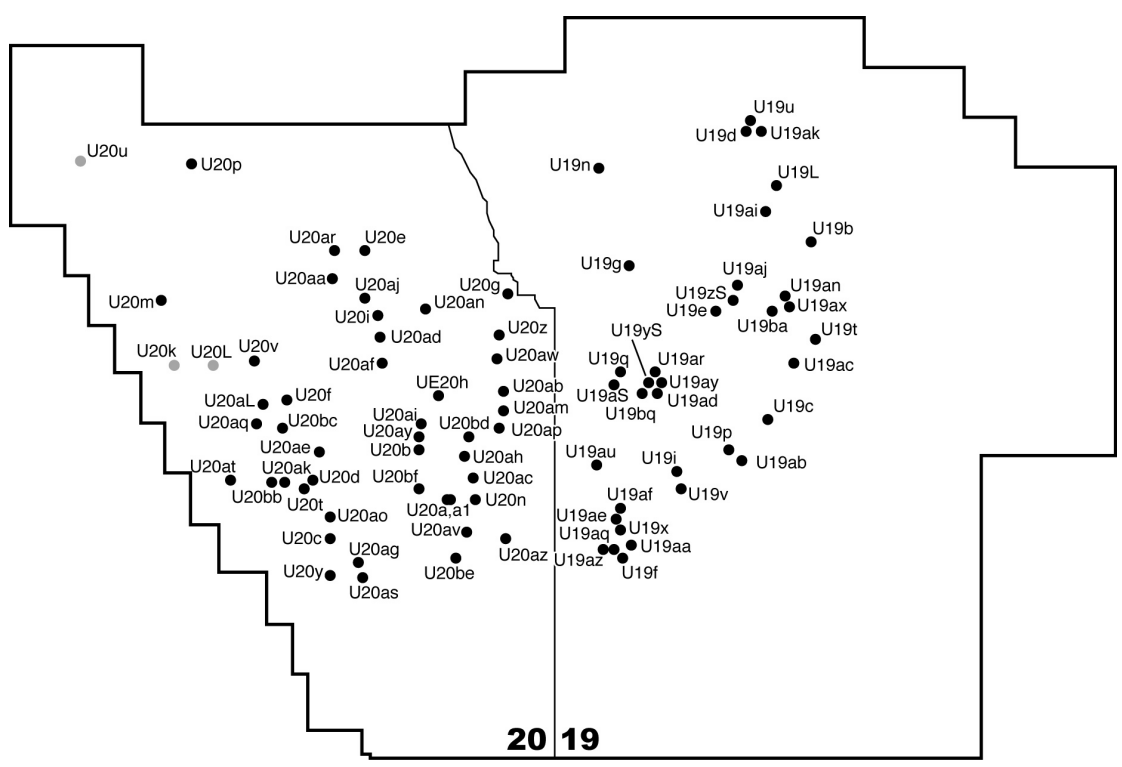

Figure 1. Locations of tests in Areas 19 and 20 at Pahute Mesa, NNSS (Pawloski et al., 2002).

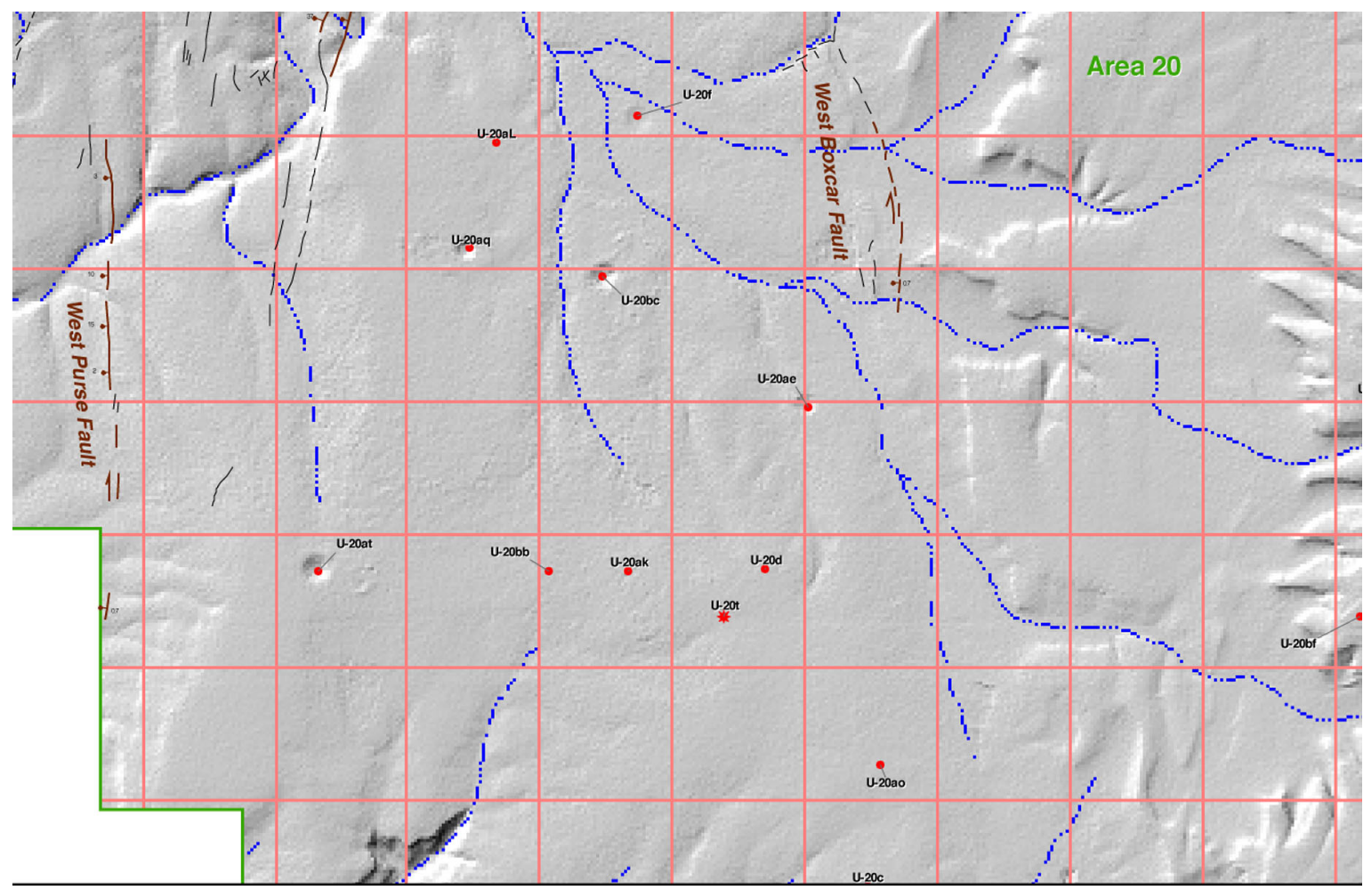

Figure 2. Locations of tests discussed in this report (based on a surface effects map from Grasso, 2003). 
Evaluation of Cavity Collapse and Surface Crater Formationat the Salut Test in U20ak

Table 1. Selected information for tests located near Salut in U20ak.

\begin{tabular}{|c|c|c|c|c|c|c|c|c|c|c|c|c|}
\hline Hole Name & U20at & U20bb & U20ak & U20t & U20d & U20ae & U20ao & U20c & U20aq & U20al & U20bc & U20f \\
\hline Test Name & Delamar & Tenabo & Salut & Chateaugay & Knickerbocker & Tafi & Goldstone & Benham & Darwin & Egmont & Hornitos & Fontina \\
\hline Test Date $^{a}$ & $4 / 18 / 87$ & $10 / 12 / 90$ & $6 / 12 / 85$ & $6 / 28 / 68$ & $5 / 26 / 67$ & $7 / 25 / 80$ & $12 / 28 / 85$ & $12 / 19 / 68$ & $6 / 26 / 86$ & $12 / 9 / 84$ & $12 / 31 / 89$ & $2 / 12 / 76$ \\
\hline WP Depth (m) & 544 & 600 & 608 & 607 & 632 & 680 & 549 & 1402 & 549 & 546 & 563 & 1218 \\
\hline WP Rock & $\begin{array}{l}\text { Zeolitized } \\
\text { Bedded } \\
\text { Tuff }\end{array}$ & $\begin{array}{l}\text { Zeolitized } \\
\text { Bedded } \\
\text { Tuff }\end{array}$ & Lava & Lava & Lava & $\begin{array}{l}\text { Zeolitized } \\
\text { Bedded } \\
\text { Tuff }\end{array}$ & Lava & $\begin{array}{l}\text { Zeolitized } \\
\text { Bedded } \\
\text { Tuff }\end{array}$ & $\begin{array}{l}\text { Zeolitized } \\
\text { Bedded } \\
\text { Tuff }\end{array}$ & $\begin{array}{l}\text { Zeolitized } \\
\text { Bedded } \\
\text { Tuff }\end{array}$ & $\begin{array}{l}\text { Zeolitized } \\
\text { Bedded } \\
\text { Tuff }\end{array}$ & $\begin{array}{l}\text { Zeolitized } \\
\text { Nonwelded } \\
\text { Tuff }\end{array}$ \\
\hline $\begin{array}{l}\text { Announced } \\
\text { Yield (kt) }\end{array}$ & $20-150$ & $20-150$ & $20-150$ & $20-200$ & 76 & $20-150$ & $20-150$ & 1150 & $20-150$ & $20-150$ & $20-150$ & $200-1000$ \\
\hline $\begin{array}{l}\text { SDOB } \\
\left(\mathrm{m} / \mathrm{kt}^{1 / 3}\right)^{\mathrm{b}}\end{array}$ & 102 & 113 & 114 & 104 & 149 & 128 & 103 & 134 & 103 & 103 & 106 & 122 \\
\hline $\begin{array}{l}\text { Calculated } \\
\text { Cavity Radius } \\
(\mathrm{m})^{\mathrm{c}}\end{array}$ & 63 & 62 & 62 & 68 & 49 & 60 & 63 & 99 & 63 & 63 & 63 & 98 \\
\hline $\begin{array}{l}\text { Hole Depth } \\
(\mathrm{m})\end{array}$ & 579 & 676 & 640 & 617 & 1279 & 716 & 655 & 1463 & 579 & 609 & 609 & 1280 \\
\hline $\begin{array}{l}\text { Water Level } \\
\text { Depth }(\mathrm{m})\end{array}$ & 605 & 609 & 608 & 616 & 613 & 584 & 627 & 629 & 561 & 544 & 567 & 538 \\
\hline $\begin{array}{l}\text { Associated } \\
\text { Holes }\end{array}$ & Inst \#1 & $\begin{array}{l}\text { Inst \#1; } \\
\text { PS1A; } \\
\text { PS1AA; } \\
\text { PS1AB; } \\
\text { PS1ABC; } \\
\text { PS1AD }\end{array}$ & $\begin{array}{l}\text { PS1A; } \\
\text { PS1AA }\end{array}$ & $\begin{array}{l}\text { PS1D; } \\
\text { PS1DS; } \\
\text { PS1DSS }\end{array}$ & $\begin{array}{l}\text { UE20d; PS1D; } \\
\text { PS1DS; } \\
\text { PS1DSS }\end{array}$ & $\begin{array}{l}\text { UE20ae; } \\
\text { PS1D }\end{array}$ & & $\begin{array}{l}\text { UE20c; } \\
\text { Inst \#1; } \\
\text { PS1D; } \\
\text { PS1DS }\end{array}$ & $\begin{array}{l}\text { PS1A; } \\
\text { PS1AA; } \\
\text { PS1AAB }\end{array}$ & PS1A & $\begin{array}{l}\text { PS1A; } \\
\text { PS1AA }\end{array}$ & $\begin{array}{l}\text { UE20f; } \\
\text { PS1D }\end{array}$ \\
\hline $\begin{array}{l}\text { Site } \\
\text { Characteristics } \\
\text { Summary? }\end{array}$ & Yes & Yes & Yes & $\begin{array}{l}\text { Geologic } \\
\text { report }\end{array}$ & Geologic report & Yes & Yes & $\begin{array}{l}\text { Geologic } \\
\text { report }\end{array}$ & Yes & Yes & Yes & Yes \\
\hline $\begin{array}{l}\text { Containment } \\
\text { Data Report? }\end{array}$ & No & Yes & Yes & No & No & No & No & No & No & No & Yes & No \\
\hline
\end{tabular}

${ }^{\mathrm{a}}$ USDOE, 2000

${ }^{\mathrm{b}}$ Assuming the maximum of the announced yield range in USDOE (2000)

${ }^{c}$ Assuming the maximum of the announced yield range in USDOE (2000) and using the equation in Pawloski (1999) 


\section{Evaluation of Cavity Collapse and Surface Crater Formationat the Salut Test in U20ak}

Figure 3 shows structural features at Pahute Mesa and Oasis Valley, including the many nested calderas that were the eruptive sources for rocks found in Pahute Mesa drill holes. West-east and southeast-north cross sections from Salut in U20ak (Figure 4) show the relatively flat lying layers of nonwelded to densely-welded ash flow tuff, bedded tuff and lavas in the structural block between the West Purse and West Boxcar faults. The tuffs and lavas have been altered by devitrification and zeolitization. The stratigraphic units are present as expected, and thickness varies (again, as expected), mainly due to location of the volcanic source, existing topography at the time of deposition, and later modification by normal faulting. The lavas in these drill holes are Paintbrush Group units and were derived from the Area 20 caldera (in yellow on Figure 3), which was buried by eruptions from younger calderas. The Rainier Mesa caldera (orange in Figure 3) and Ammonia Tanks caldera (green in Figure 3), also now buried, were the sources for the Rainier Mesa and Ammonia Tanks tuffs. Based on stratigraphy penetrated by drill holes near U20ak, lavas are thicker and more frequently present near U20c and U20ao. Timber Mountain Tuffs (Ammonia Tanks and Rainier Mesa members) are thickest near U20aq, U20al, U20bc and U20f.

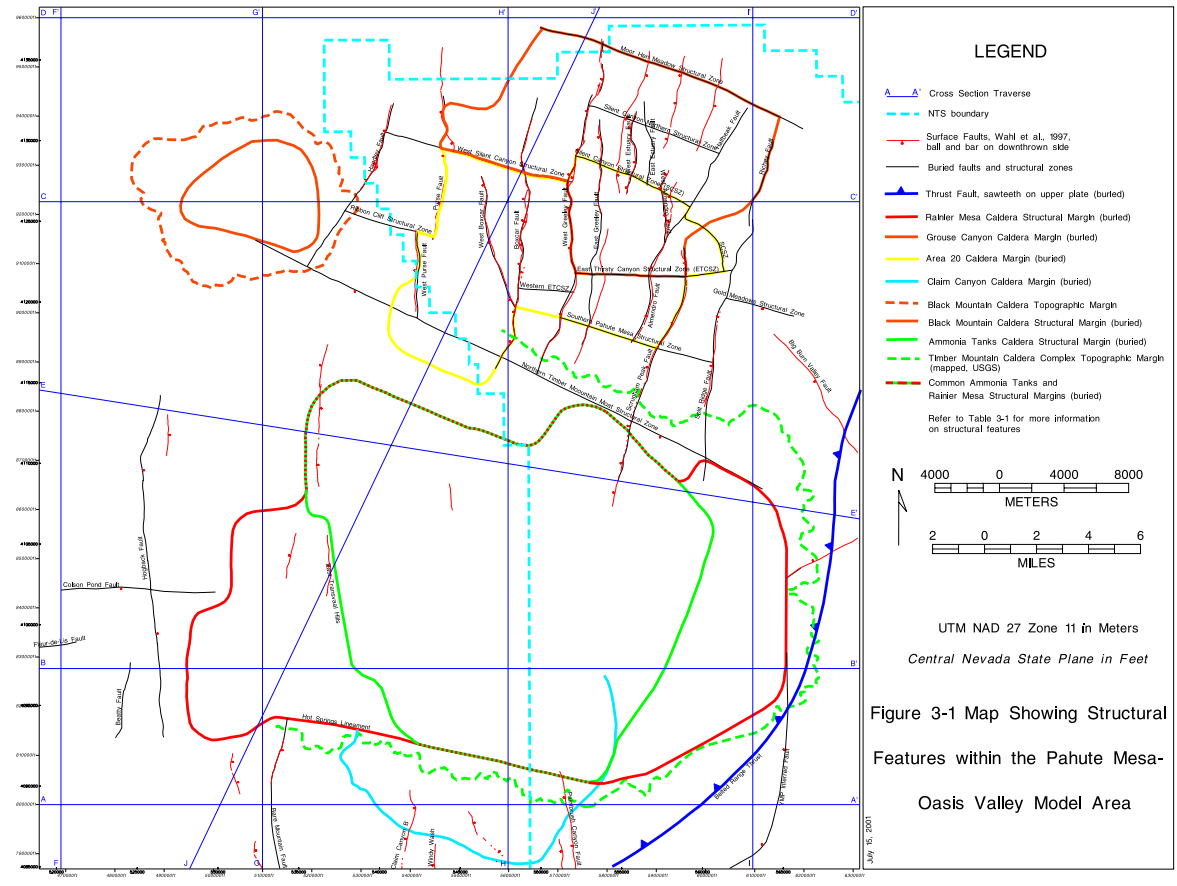

Figure 3. Location of the Area 20 Caldera between the West Purse and West Boxcar faults on Pahute Mesa, NNSS (figure extracted from Bechtel Nevada, 2002). 
Evaluation of Cavity Collapse and Surface Crater Formationat the Salut Test in U20ak

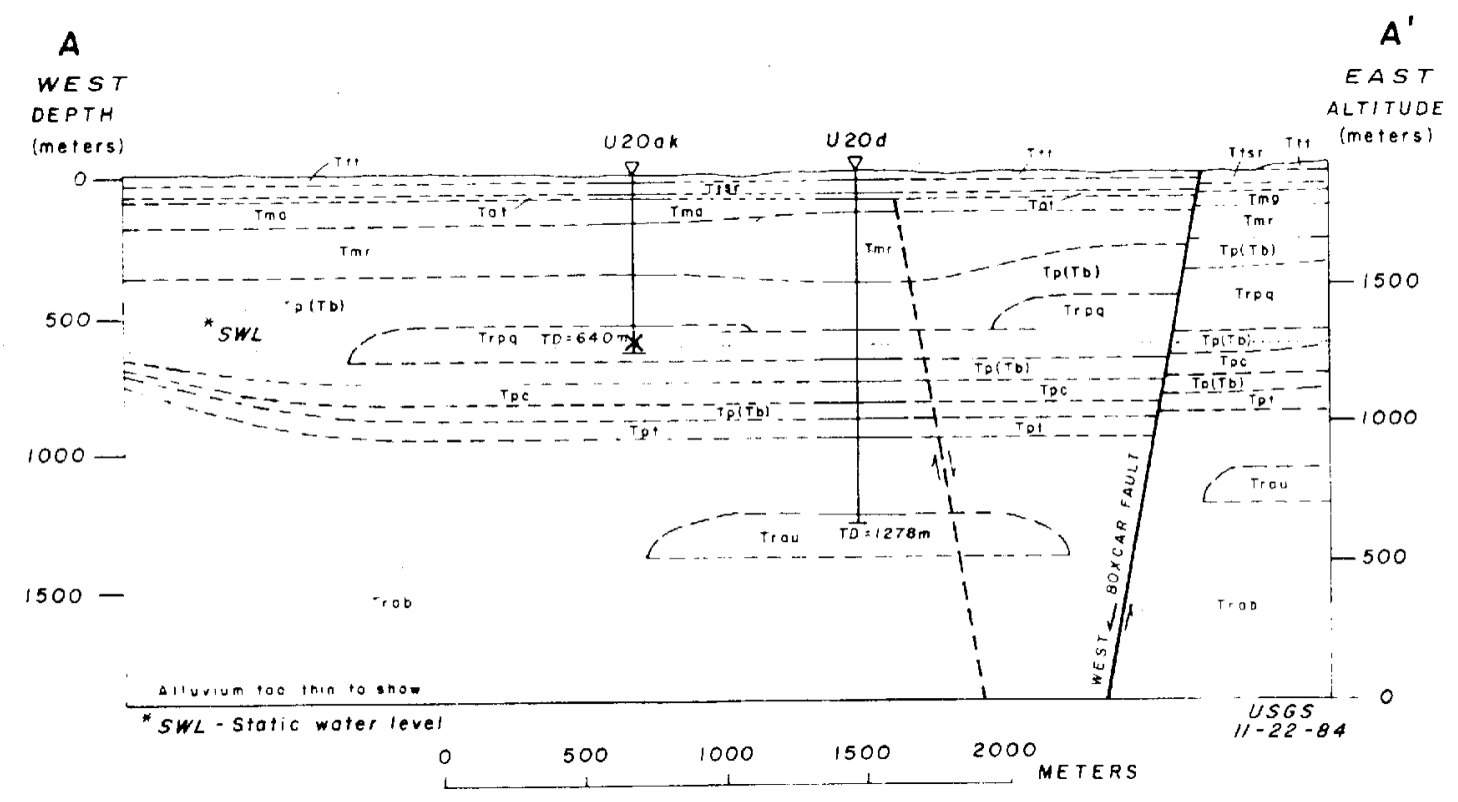

Fast-West (A-A') geologic cross section through the U2Oak site

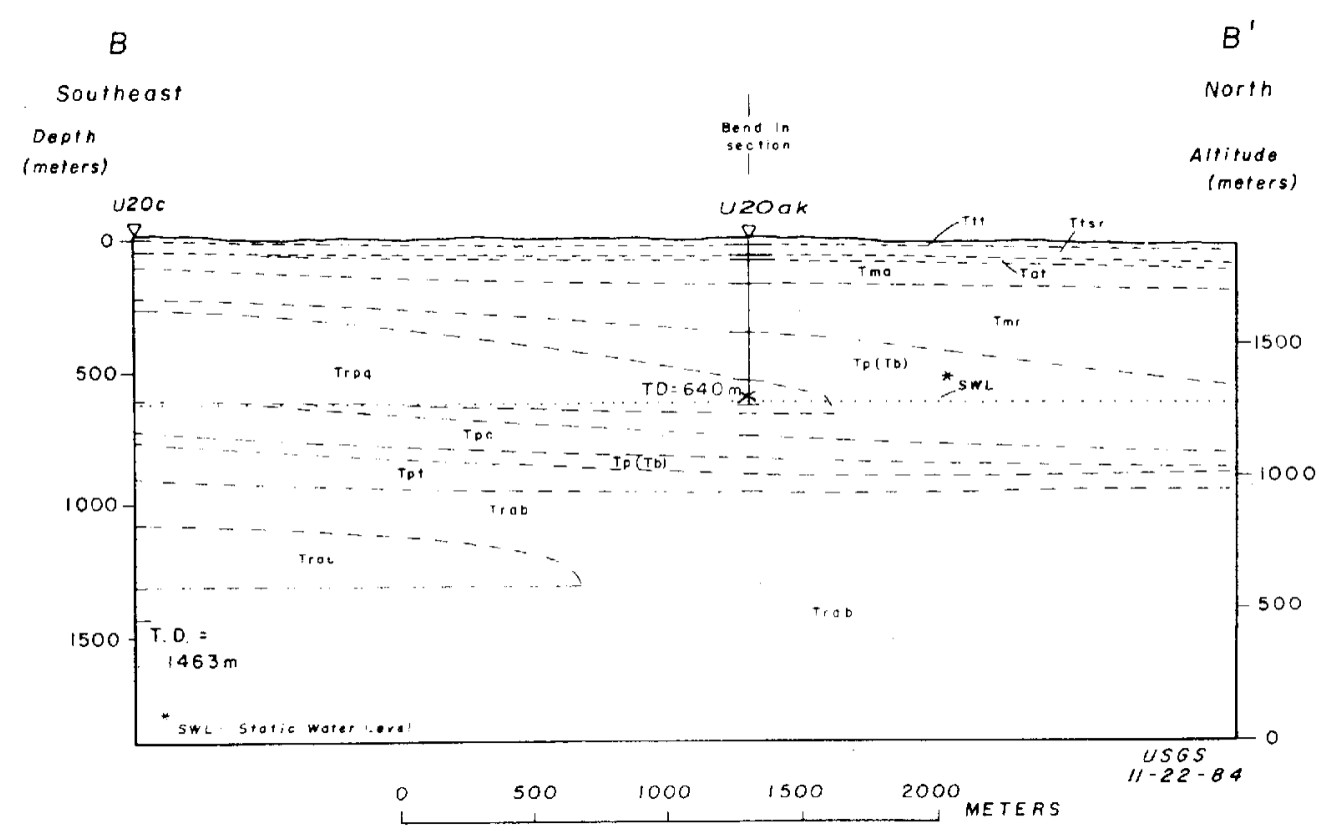

Southeast-North (B-B') geologic cross section through the U2Oak site

Figure 4. West-east and southeast-north cross sections of the U20ak site (Pawloski, 1985). Note that the stratigraphic nomenclature for the NNSS has been updated since this report was published. 


\section{Evaluation of Cavity Collapse and Surface Crater Formationat the Salut Test in U20ak}

We have reviewed geology and test-related data for Salut.

From a containment point of view, the Salut underground nuclear test behaved normally and was satisfactorily contained.

- Cavity-chimney collapse occurred 10 hours and 17 minutes after detonation and did not reach the surface. Two CLIPER cables in the emplacement hole indicated that subsurface collapse progressed upward to a depth of about $268 \mathrm{~m}$ and $282 \mathrm{~m}$. Acceleration and velocity instrumentation in a plug at about $345 \mathrm{~m}$ and in coarse stemming material at about $290 \mathrm{~m}$ were lost, indicating they were consumed by collapse. A large pressure drop below the stemming platform at $200 \mathrm{~m}$ was charateristic of a stemming fall below this structural platform (stemming platforms are designed to hold stemming above them in place). Velocimeter data at $290 \mathrm{~m}$ indicates the instrument was "springing" suspended in free space for a few seconds before it was lost. A slow increase in pressure after collapse suggested restricted communication with the chimney region. No collapse motion signals were seen from instrumentation near the top stemming platform at $70 \mathrm{~m}$, suggesting stemming is in place above $60 \mathrm{~m}$ and subsurface collapse stopped below the stemming platform at $200 \mathrm{~m}$.

Two explanations describing subsurface collapse height can be interpreted. Both suggest that subsurface collapse affecting in-situ material occurred to somewhere between 268 and $282 \mathrm{~m}$ depth. Both support a lack of stemming in the emplacement hole to $200 \mathrm{~m}$, below the stemming platform. The remaining questions are: How high did subsurface collapse in the native, in-situ rock proceed? Is the native rock in place above $268 \mathrm{~m}$ and a void present in the hole to $200 \mathrm{~m}$ ? Or, did subsurface collapse of the in-situ material proceed to $200 \mathrm{~m}$, leaving a rubble column of native rock to this depth? Could subsurface collapse have proceeded to some depth between 268 and $200 \mathrm{~m}$ ? We have no data to address these questions.

- No radiation above ambient levels was observed at any instrument station in the emplacement hole; there is no indication of any radiation moving up hole caused by the detonation or resulting subsurface collapse.

- Relatively few surface effects were caused by Salut. Figure 5 shows minor cracking and a linear crack with small displacement to the south. For comparison, Figure 6 shows surface effects caused by nearby tests (note scale differences among these figures).

- At $150 \mathrm{kt}$, the maximum of the announced yield range for Salut, the calculated SDOB is $114 \mathrm{~m} / \mathrm{kt}^{1 / 3}$. The Containment rule of thumb for collapse to the surface at Pahute Mesa notes that tests with SDOBs less than $118 \mathrm{~m} / \mathrm{kt}^{1 / 3}$ collapse to the surface. Assuming the maximum of the yield range, and not taking geology into account, Salut should have collapsed to the surface.

- Strong geologic units, defined by high bulk density and high seismic velocity, occur in U20ak from 166-350 m (Rainier Mesa welded tuff) and from 500 to $640 \mathrm{~m}$ at the bottom of the emplacement hole (Paintbrush Benham lavas). Measurements in the hole indicate subsurface collapse progressed above the lavas but terminated somewhere in the Rainier Mesa tuffs. Minor cooling cracks are present in the welded Rainier Mesa tuffs from about 170-215 m, and there are two lithophysae zones, from 220 to $260 \mathrm{~m}$ and 275 to $325 \mathrm{~m}$. It seems logical that if collapse extended into the Rainier Mesa tuffs, rock 


\section{Evaluation of Cavity Collapse and Surface Crater Formationat the Salut Test in U20ak}

strength could be sufficient to terminate collapse and provide a stable setting. However, it is not clear how zones in the Rainier Mesa tuffs could influence the progress of subsurface collapse, or better define a depth where subsurface collapse would terminate.

- The ground surface at the U20ak site has not changed over time since the test. There were 27 tests on Pahute Mesa after Salut that caused subsequent ground motion. Of the 12 tests in this locality, five were conducted after Salut, providing significant ground motion near the Salut collapse cavity-chimney. 
Evaluation of Cavity Collapse and Surface Crater Formationat the Salut Test in U20ak

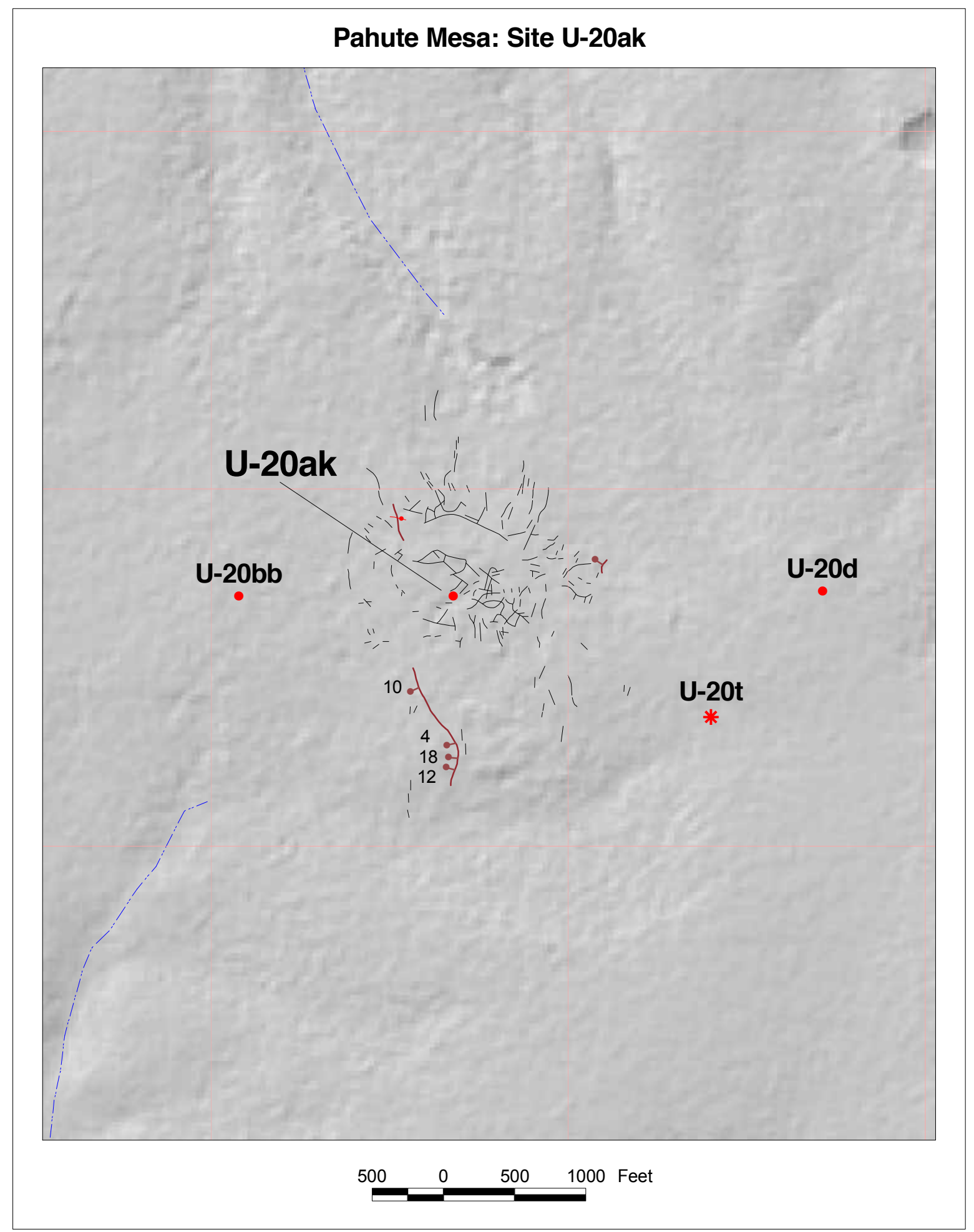

Figure 5. Surface effects map of Salut in U20ak (Grasso, 2003). 


\section{Evaluation of Cavity Collapse and Surface Crater Formationat the Salut Test in U20ak}
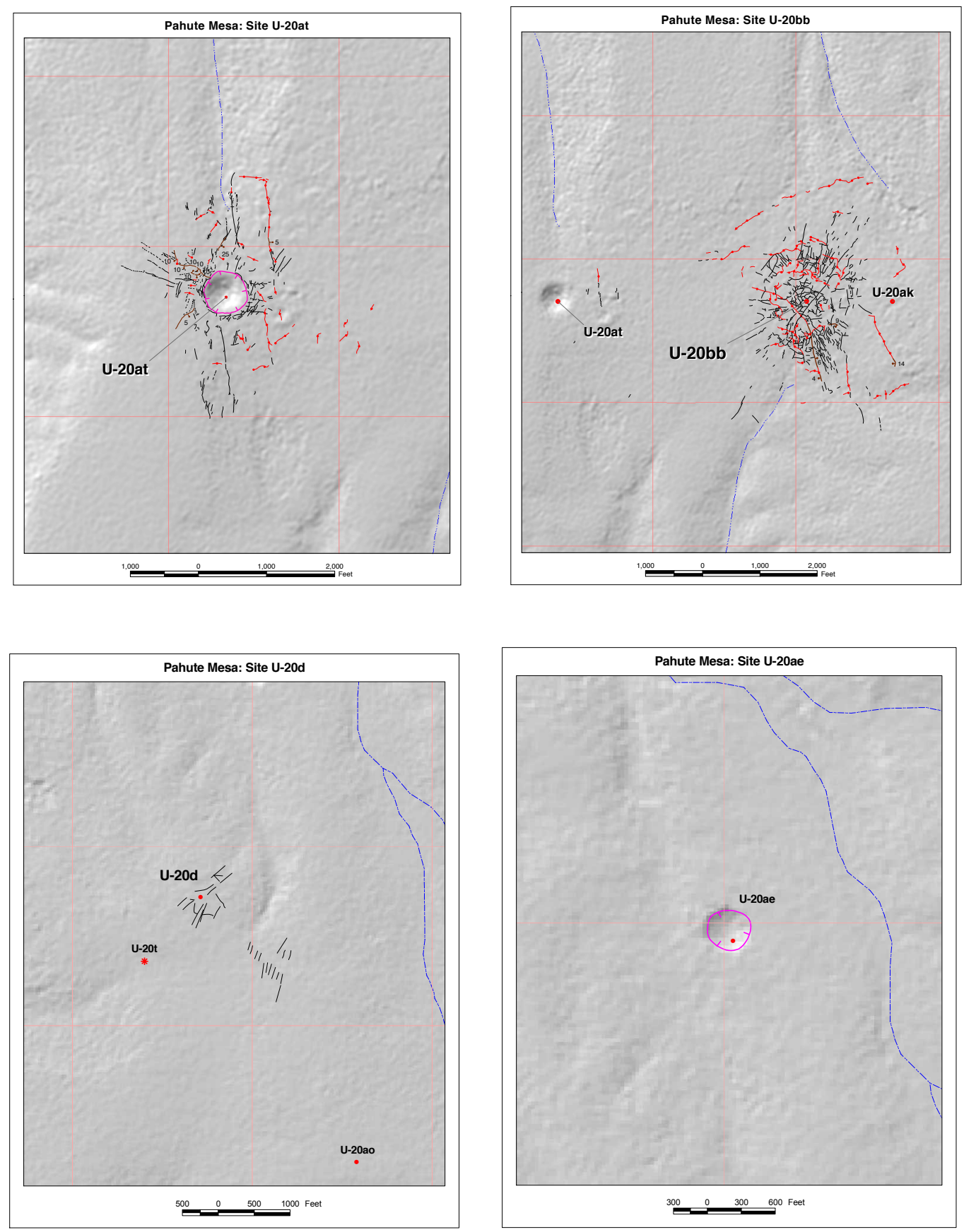


\section{Evaluation of Cavity Collapse and Surface Crater Formationat the Salut Test in U20ak}
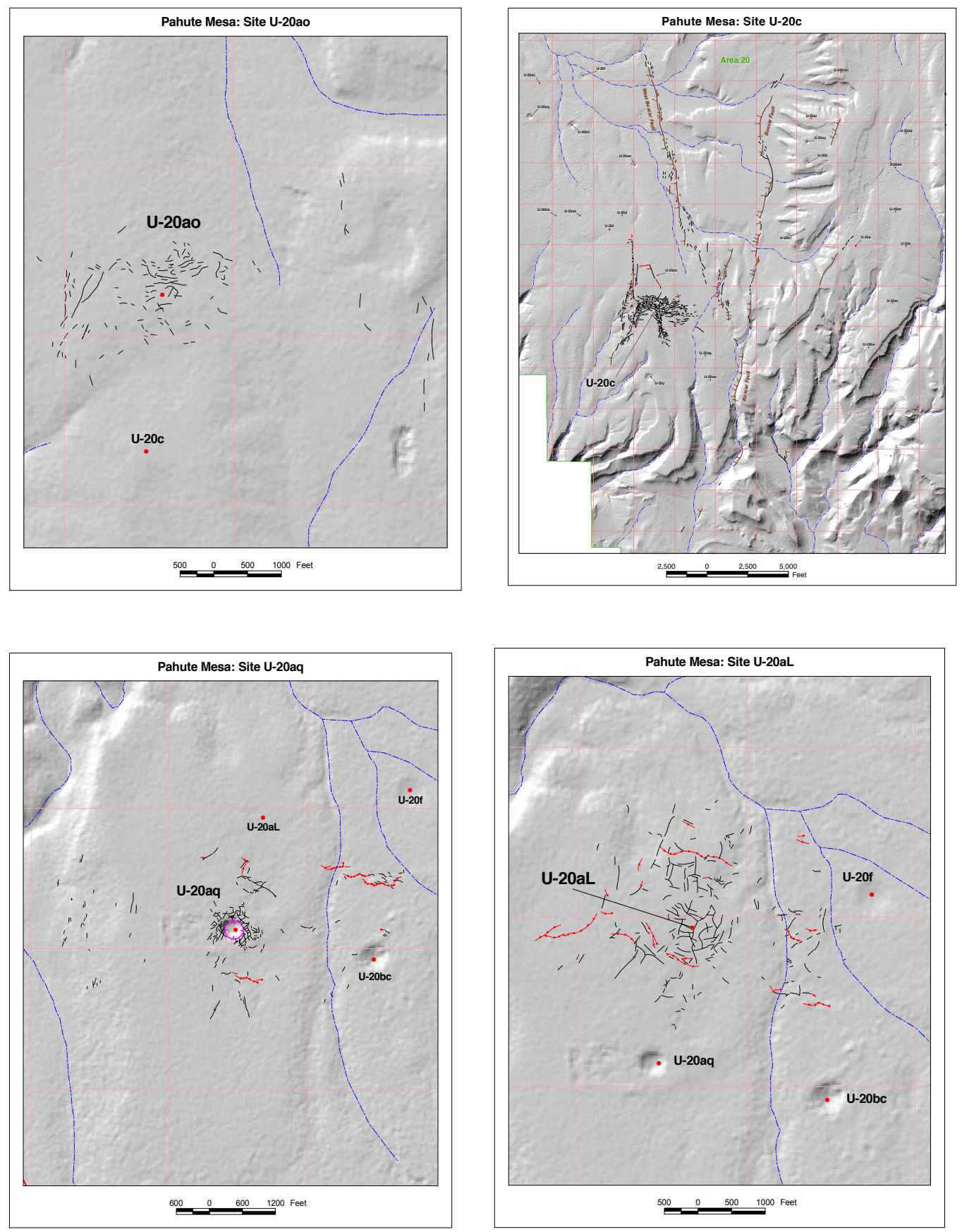

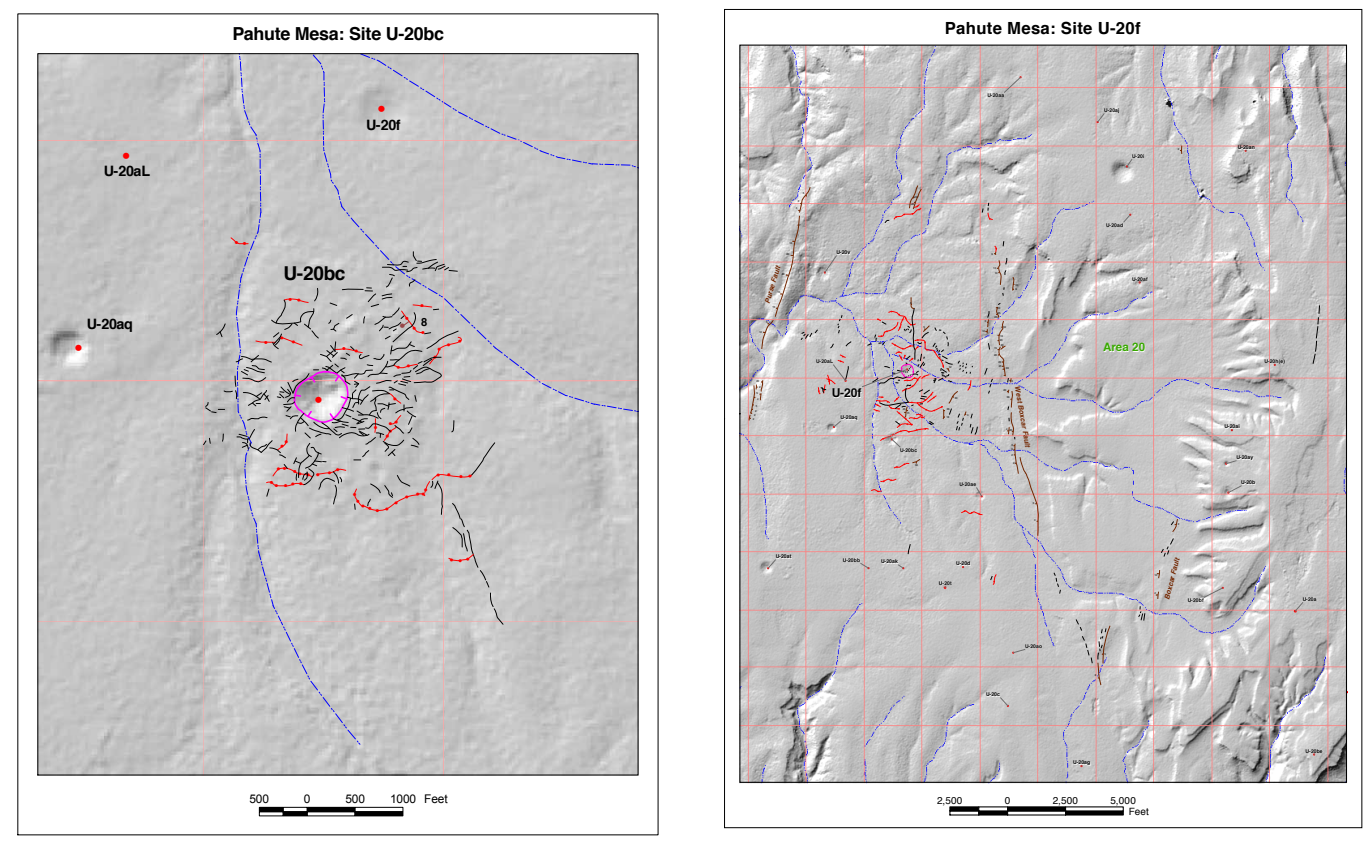

Figure 6. Surface effects from tests located near Salut in U20ak: Delamar in U20at, Tenabo in U20bb, Knickerbocker in U20d, Tafi in U20ae, Goldstone in U20ao, Benham in U20c, Darwin in U20aw, Egmont in U20al, Hornitos in U20bc, and Fontina in U20f. Chateaugay in U20t did not produce any surface effects.

\section{Evaluating Data from Nearby Tests}

To assist in evaluating if the surface area over Salut in U20ak is sufficiently stable to support field activities, it is important to address the completeness and stability of subsurface collapse. The first step is to understand the geologic setting and determine if the rock layers in this structural block are consistent and predictable. The second step is to compare test-related data, specifically data related to collapse, to determime if collapse height correlates to geology, and then determine if layers can provide a stable configuration for subsurface collapse.

The geologic evaluation included the twelve tests previously mentioned, several more tests located to the north and south, and several groundwater characterization wells also to the south. All are located in the same structural block.

- Purse in U20v, about $4 \mathrm{~km}$ north of Salut.

- Tybo in U20y, Molbo in U20ag, and Belmont in U20as, at greater than $3 \mathrm{~km}$ south of Salut.

- Groundwater characterization wells ER-20-1, ER-20-5 \#1 and \#3, and ER-20-7, at greater than $3 \mathrm{~km}$ south of Salut. 
Evaluation of Cavity Collapse and Surface Crater Formationat the Salut Test in U20ak

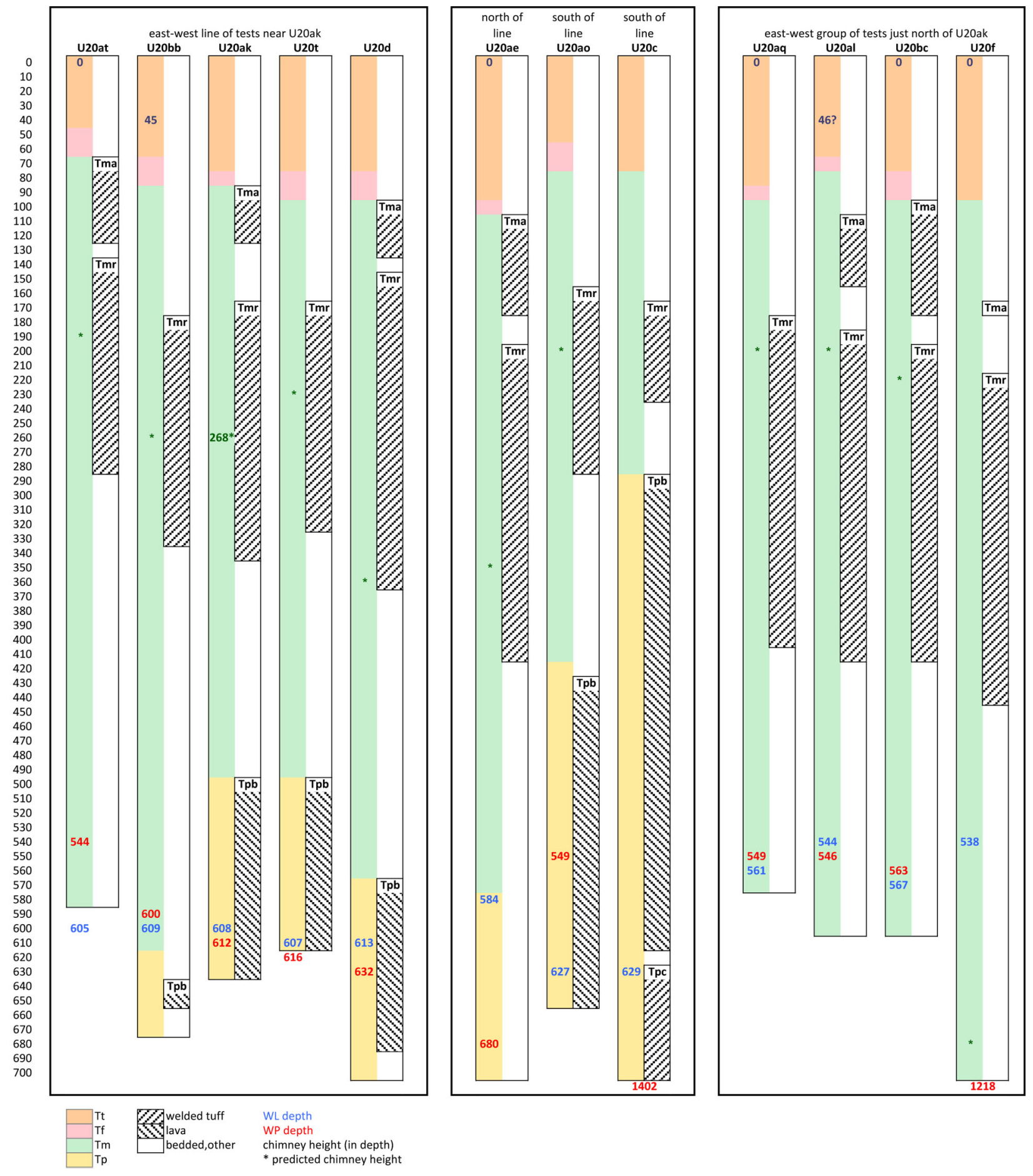

Figure 7. Schematic correlating stratigraphy and lithology for the 12 tests near Salut in U20ak. 


\section{Evaluation of Cavity Collapse and Surface Crater Formationat the Salut Test in U20ak}

Figure 7 is a schematic correlating stratigraphy and lithology for the tests near Salut using data collected over a wide time frame. Early data (in the 1960s) is from USGS reports compiled soon after holes were first drilled at Pahute Mesa. Site characterizations supporting the weapons testing program provided a large set of data. Several new wells were drilled at Pahute Mesa after the testing program concluded. The Underground Test Area Project has reevaluated all of this data to develop a hydrostratigraphic model to evaluate groundwater contamination from underground nuclear testing, and these efforts have dramatically improved understanding of the geologic structural model. The simple correlation diagram shown in Figure 7, combined with the cross sesctions shown in Figure 4, clearly indicate that the units near U20ak are relatively flat lying, and differences in thickness can be attributed to nearness to the source origin, existing topography at the time of deposition, and later normal faulting. Within the depth range shown in Figure 7, Paintbrush lavas (Tpb) and ash flow tuffs (Tpc) are surrounded by zeolitized tuffs. Timber Mountain tuffs (Rainier Mesa tuff [Tmr] and Ammonia Tanks tuff [Tma]) are also surrounded by zeolitized tuffs. Not distinguishable in this figure are the thinner alternating ash flows and bedded tuffs of Fortymile Canyon (Tf) and Thirsty Canyon (Tt) near the top $100 \mathrm{~m}$ of the drillholes.

It is important to note that while there is confidence in making generalizations about the extent of the stratigraphic and lithologic units from the WP to the surface, we do not know much about the spatial variability of smaller scale features found within the drill holes, nor their continuity outside the drill holes.

Test-related data was reviewed to help evaluate if Salut subsurface collapse is stable. Table 2 presents information on WP rock type, yield-related parameters, height of collapse, collapse time, and surface crater features. The goal is to determine if there are patterns or thresholds related to collapse height and stability of subsurface collapse for tests in this locality.

Table 2 shows that ten of the twelve tests (including Salut) had similar yields, ranging between 76 to $200 \mathrm{kt}$ (at the maximum of the announced yield range). Two tests (Fontina and Benham) were part of the higher yield testing program that occurred at Pahute Mesa during the 1960s1970s, and had larger yields (1000 kt and $1150 \mathrm{kt}$ ).

Of the ten tests with a similar announced yield range, six experienced subsurface collapse. Four of these had similar WP depths, and two were slightly shallower. Four of the ten tests collapsed to the surface. Three of these had a slightly shallower WP depth, and one was slightly deeper. No clear conclusions can be drawn about WP depth and surface collapse.

WP depth, SDOB, and cavity radius all relate to yield. WP depths are designed to contain planned yields, based on Containment rules of thumb and other experience. It is not surprising that WP and cavity radius values in Table 2 are bimodal, correlating to yield distribution. SDOB, which scales kilotons of yield to meters of depth, is designed to remove correlations between yield and depth. The calculated SDOBs for all twelve of these test range between 102 to $149 \mathrm{~m} / \mathrm{kt}^{1 / 3}$.

Would collapse to the surface have been predicted for any of these tests, based on SDOB, WP rock, or collapse information?

- The SDOB rule of thumb says that tests at Pahute Mesa collapse to the surface if the SDOB is less than $118 \mathrm{~m} / \mathrm{kt}^{1 / 3}$. Table 2 shows that five of the twelve tests collapsed to the surface, with SDOBs ranging from 102 to $128 \mathrm{~m} / \mathrm{kt}^{1 / 3}$. Seven of the twelve tests 


\section{Evaluation of Cavity Collapse and Surface Crater Formationat the Salut Test in U20ak}

experienced subsurface collapse, with SDOBs ranging from 103 to $149 \mathrm{~m} / \mathrm{kt} 1 / 3$. Note the overlapping range of SDOB data and lack of compliance to the rules of thumb for surface collapse.

- WP rock type has been known to influence cavity growth, mainly related to the strength of the host rock. Can WP rock be used to predict collapse? As identified in Table 2 and shown in Figure 7, 4 of the twelve tests had WPs located in lava, and all four experienced subsurface collapse. Eight tests had WPs in zeolitized bedded and nonwelded tuff, where five collapsed to the surface and three did not. SDOBs for lava WPs range from 103 to $149 \mathrm{~m} / \mathrm{kt} 1 / 3$, while SDOBs for zeolitized bedded and nonwleded tuffs ranged from 103 to $134 \mathrm{~m} / \mathrm{kt} 1 / 3$. Note again the overlapping range of SDOB data and lack of compliance to the rule of thumb for surface collapse.

- To help understand if WP rock can influence collapse to the surface, the entire population of underground nuclear tests at Pahute Mesa tests was reviewed. Sixty of the eighty-two tests - 73\% - did not collapse to the surface. Of the tests that did not collapse to the surface, $60 \%$ of the WPs were in stronger rock (mainly lavas) and $40 \%$ of the WPs were in less strong rock (mainly zeolitized tuffs). The $27 \%$ of tests that did collapse to the surface were evenly divided between stronger and less strong WP rocks. While one may be tempted to conclude that WPs in stronger rocks tend to not collapse to the surface, it is important to note that other factors besides WP rock will influence collapse, including yield, WP depth, geologic setting, and rock properties.

- How does measured subsurface collapse height (also known as chimney height) relate to the Containment rule of thumb of 5.5 +/-2.0 Rc? Data exists for eight of these twelve tests, where subsurface collapse height is known or collapse proceeded to the ground surface. Table 2 shows that collapse height ranges from 5.5 to 12.4 Rc. The lowest value is for Salut, which is exactly on the rule of thumb at $5.5 \mathrm{Rc}$, and where measured data support the subsurface collapse height. All other values range from 8.6 to $12.4 \mathrm{Rc}$, and are outside the error associated with the rule of thumb.

- Figure 7 shows, with an asterisk, the location of predicted chimney height based on the $5.5 \mathrm{Rc}$ rule of thumb. For ten of the tests, predicted subsurface collapse would terminate in the moderately to densely welded Rainier Mesa tuff, which is present over the entire structural block. It is thicker to the north compared to the south, and slightly thicker in holes to the east (nearer the source) compared to holes in the west. It is about 125 to $235 \mathrm{~m}$ thick over the width of the structural block near the ten tests. It is clear that subsurface collapse for Salut terminated somewhere in the Rainier Mesa tuff. It seems possible that this unit can serve as a significantly strong feature that can teminate collapse as it progresses upward. That said, collapse for two tests (Tenabo in U20bb and Egmont in U20al) progressed through the Rainier Mesa tuff and terminated in the Thirsty Canyon tuffs, quite near but not at the ground surface.

- In general, collapse can terminate as a subsurface chimney (with or without an apical void) or with a crater at the ground surface. Studies have evaluated possible links between surface crater size, cavity void space and bulking factors, with limited success. Collapse times exist for seven of the twelve tests tests near Salut. They range from 0.05 minutes ( 3 seconds, considered quite fast) to 3665 minutes ( $2 \frac{1}{2}$ days, a bit long). The average is 860 minutes, and Salut at 619 minutes appears to be "average". 


\section{Evaluation of Cavity Collapse and Surface Crater Formationat the Salut Test in U20ak}

- Collapse rates were usually determined from cable shortening as rock failure progressed up the hole. Information on collapse rate is available for only three of the twelve tests, and the three values are quite different. The wide range of values in a small data set suggests that these values should be used with considerable caution.

Finally, it is important to realize that Containment rules of thumb were developed based on what was considered accurate data sets (i.e. classified data) and may not hold true because of limitations when using unclassified data. It is apparent in this evaluation that using the maximum of the announced yield range for tests affects application of Containment rules of thumb relating SDOB to collapse and cavity radius to chimney height. The impact of using unclassified data may be so severe that these rules of thumb are not applicable.

\section{Potential Issues at the Ground Surface}

It is important to note that all twelve tests in this locality were successfully contained. However, four experienced operational releases, as identified in Radiological Effluents Released from U.S. Continental Tests 1961 through 1992 (USDOE, 1996), and shown in Table 3. At Salut, drillback activity released ${ }^{133} \mathrm{Xe},{ }^{133 \mathrm{~m}} \mathrm{Xe}$, and ${ }^{135} \mathrm{Xe}$, and a controlled gas sampling containment tank released ${ }^{3} \mathrm{H},{ }^{85} \mathrm{Kr},{ }^{127} \mathrm{Xe},{ }^{133} \mathrm{Xe},{ }^{133 \mathrm{~m}} \mathrm{Xe},{ }^{131} \mathrm{I}$ and tritiated water. Care should be taken to evaluate if any lingering effects are still present at the surface before surface work is initiated.

\section{Conclusions}

We think we know when cavity collapse occurred for Salut (roughly ten hours after detonation), and we think we know how high the collapse chimney progressed (to 268 to $282 \mathrm{~m}$ depth based on CLIPER cables, but it could be as high as $200 \mathrm{~m}$ depth, the position of the stemming fall in the emplacement hole). It appears that some portion of the Rainier Mesa densely welded tuff terminated subsurface collapse. Standard LLNL procedure is that cable lengths are not monitored for very long after collapse, so we do not know if subsurface collapse has changed over time. Since the ground surface above the U20ak site has not changed due to shaking from subsequent tests, it seems reasonable to conclude that the current surface configuration at U20ak should be stable. However, because this site exhibited subsurface collapse and there is only a small data set to draw conclusions from, LLNL has less confidence than normal in making this statement.

Data from nearby tests was evaluated to address the completeness and stability of the subsurface collapse at Salut in U20ak, to help determine if the surface area is sufficiently stable to support field activities in this locality.

Evaluation of the geologic setting in the structural block bounded by the West Purse Fault to the west and the West Boxcar Fault to the east indicates the geologic units near U20ak are present as expected - the units are relatively flat lying, and differences in thickness can be attributed to nearness to the source origin, existing topography at the time of deposition, and later normal faulting. Welded ash flow tuffs exist in sufficient thickness to influence cavity collapse at depth - specifically the Rainier Mesa tuff (Salut in U20ak) and Thirsty Canyon tuffs (Tenabo in U20bb and Egmont in U20al). Note that tests with the same anounced yield range but slightly smaller WP depths have collapsed all the way to the surface (Delamar in U20at, Darwin in U20aq, and Hornitos in U20bc). Geology itself is not an indicator of collapse height. 


\section{Evaluation of Cavity Collapse and Surface Crater Formationat the Salut Test in U20ak}

Tests in this locality that collapsed to the surface and those that experienced subsurface collapse can not be distinguished by SDOB values. The Containment rule of thumb stating that tests at Pahute Mesa with SDOB less than $118 \mathrm{~m} / \mathrm{kt}^{1 / 3}$ will collapse to the ground surface does not seem to apply here.

The subsurface collapse at Salut was terminated by welded Rainier Mesa tuffs that are about $180 \mathrm{~m}$ thick. This formation is present over the entire structural block, in thickness varying from 125 to $235 \mathrm{~m}$. The Containment rule of thumb for predicting the height of subsurface collapse for nearby tests suggests that welded Rainier Mesa tuff is at a position $(5.5 \mathrm{Rc})$ to terminate subsurface collapse. (Note that some tests of similar, slightly shallower, and slightly deeper WP depths collapsed to the surface, collapsing through the strong Rainier Mesa tuffs.)

Using Containment rules of thumb - SDOB for predicting tendency for surface collapse and cavity radius to predict subsurface collapse height - is insightful but not conclusive. This is most likely due to application of unclassified data which forces use of the maximum of the announced yield range, and the rules of thumb were established using more accurate (i.e. classified) data.

From a Containment point of view, it is clear that the dynamics of cavity collapse, leading to surface or subsurface collapse, is complete. It is reasonable that the current subsurface and surface collapse area configurations should be considered stable. The ground surface above all of these tests has not changed over time, so it seems reasonable to conclude that the current configurations are stable.

However, what is not clear is predicting the stability of the ground surface to permit access and field activities. It seems likely that the Rainier Mesa tuffs, present within a band of about 150$400 \mathrm{~m}$ in depth, has an impact of subsurface collapse in this locality. It is also possible that subsurface collapse can terminate in the Thirsty Canyon tuffs, much nearer the ground surface (around $45 \mathrm{~m}$ depth). Significant ground motion has occurred due to underground nuclear testing, and one might think that the current configurations are sufficiently stable to permit access to the ground surface above Salut in U20ak. We have evaluated crater stability produced from cavity collapse, and have not considered later erosion effects. We rely on NSTec and DOE/NNSA/NSO to make decisions concerning safety issues related to reentering the area above Salut. 
Evaluation of Cavity Collapse and Surface Crater Formationat the Salut Test in U20ak

Table 2 Selected collapse information for tests near Salut in U20ak.

\begin{tabular}{|c|c|c|c|c|c|c|c|c|c|c|c|c|}
\hline Hole Name & U20at & U20bb & U20ak & U20t & U20d & U20ae & U20ao & U20c & U20aq & U20al & U20bc & U20f \\
\hline Test Name & Delamar & Tenabo & Salut & Chateaugay & Knickerbocker & Tafi & Goldstone & Benham & Darwin & Egmont & Hornitos & Fontina \\
\hline Test Date $^{a}$ & $4 / 18 / 87$ & $10 / 12 / 90$ & $6 / 12 / 85$ & $6 / 28 / 68$ & $5 / 26 / 67$ & $7 / 25 / 80$ & $12 / 28 / 85$ & $12 / 19 / 68$ & $6 / 26 / 86$ & $12 / 9 / 84$ & $12 / 31 / 89$ & $2 / 12 / 76$ \\
\hline WP Depth (m) & 544 & 600 & 608 & 607 & 632 & 680 & 549 & 1402 & 549 & 546 & 563 & 1218 \\
\hline WP Rock & $\begin{array}{l}\text { Zeolitized } \\
\text { Bedded } \\
\text { Tuff }\end{array}$ & $\begin{array}{l}\text { Zeolitized } \\
\text { Bedded } \\
\text { Tuff }\end{array}$ & Lava & Lava & Lava & $\begin{array}{l}\text { Zeolitized } \\
\text { Bedded } \\
\text { Tuff }\end{array}$ & Lava & $\begin{array}{l}\text { Zeolitized } \\
\text { Bedded } \\
\text { Tuff }\end{array}$ & $\begin{array}{l}\text { Zeolitized } \\
\text { Bedded } \\
\text { Tuff }\end{array}$ & $\begin{array}{l}\text { Zeolitized } \\
\text { Bedded } \\
\text { Tuff }\end{array}$ & $\begin{array}{l}\text { Zeolitized } \\
\text { Bedded } \\
\text { Tuff }\end{array}$ & $\begin{array}{l}\text { Zeolitized } \\
\text { Nonwelded } \\
\text { Tuff }\end{array}$ \\
\hline $\begin{array}{l}\text { Announced } \\
\text { Yield (kt) }\end{array}$ & $20-150$ & $20-150$ & $20-150$ & $20-200$ & 76 & $20-150$ & $20-150$ & 1150 & $20-150$ & $20-150$ & $20-150$ & $200-1000$ \\
\hline SDOB $\left(\mathrm{m} / \mathrm{kt}^{1 / 3}\right)^{b}$ & 102 & 113 & 114 & 104 & 149 & 128 & 103 & 134 & 103 & 103 & 106 & 122 \\
\hline $\begin{array}{l}\text { Calculated } \\
\text { Cavity Radius } \\
(\mathrm{m})^{\mathrm{c}}\end{array}$ & 63 & 62 & 62 & 68 & 49 & 60 & 63 & 99 & 63 & 63 & 63 & 98 \\
\hline Collapse Type & Surface & Subsurface & Subsurface & Subsurface & Subsurface & Surface & Subsurface & Subsurface & Surface & Subsurface & Surface & Surface \\
\hline $\begin{array}{l}\text { Collapse } \\
\text { Height (m } \\
\text { depth) }\end{array}$ & 0 & 45 & 268 & & & 0 & & & 0 & 46 & 0 & 0 \\
\hline $\begin{array}{l}\text { Collapse } \\
\text { Height (Rc) }\end{array}$ & 8.6 & 8.9 & 5.5 & & & 11.3 & & & 8.7 & 7.9 & 8.9 & 12.4 \\
\hline $\begin{array}{l}\text { Collapse } \\
\text { Height at } 5.5 \\
\text { Rc (m depth) }\end{array}$ & 197 & 259 & 267 & 233 & 362 & 350 & 202 & 857 & 202 & 199 & 216 & 679 \\
\hline $\begin{array}{l}\text { Collapse Time } \\
\text { (min) }\end{array}$ & 649 & 0.05 & 619 & & & 273 & & & 266 & & 550 & 3665 \\
\hline $\begin{array}{l}\text { Measured } \\
\text { Collapse Rate } \\
\text { (m/sec) }\end{array}$ & & 154 & 16.5 & & & & & & & & $225 ?$ & \\
\hline $\begin{array}{l}\text { Surface } \\
\text { Collapse Crater } \\
\text { Diameter }(\mathrm{m})\end{array}$ & 180 & & & & & 114 & & & 103 & & 164 & 254 \\
\hline $\begin{array}{l}\text { Surface } \\
\text { Collapse Crater } \\
\text { Depth }(\mathrm{m})\end{array}$ & 18 & & & & & 8 & & & 11 & & 17 & 6 \\
\hline
\end{tabular}

${ }^{\mathrm{a}}$ USDOE, 2000

${ }^{b}$ Assuming the maximum of the announced yield range in USDOE (2000)

${ }^{c}$ Assuming the maximum of the announced yield range in USDOE (2000) and using the equation in Pawloski (1999) 
Evaluation of Cavity Collapse and Surface Crater Formationat the Salut Test in U20ak

Table 3. Selected release information for tests near Salut in U20ak.

\begin{tabular}{|c|c|c|c|c|c|c|c|c|c|c|c|c|}
\hline Hole Name & U20at & U20bb & U20ak & U20t & U20d & U20ae & U20ao & U20c & U20aq & U20al & U20bc & U20f \\
\hline Test Name & Delamar & Tenabo & Salut & Chateaugay & Knickerbocker & Tafi & Goldstone & Benham & Darwin & Egmont & Hornitos & Fontina \\
\hline Test Date $^{a}$ & $4 / 18 / 87$ & $10 / 12 / 90$ & $6 / 12 / 85$ & $6 / 28 / 68$ & $5 / 26 / 67$ & $7 / 25 / 80$ & $12 / 28 / 85$ & $12 / 19 / 68$ & $6 / 26 / 86$ & $12 / 9 / 84$ & $12 / 31 / 89$ & $2 / 12 / 76$ \\
\hline $\begin{array}{l}\text { WP Depth } \\
\text { (m) }\end{array}$ & 544 & 600 & 608 & 607 & 632 & 680 & 549 & 1402 & 549 & 546 & 563 & 1218 \\
\hline WP Rock & $\begin{array}{l}\text { Zeolitized } \\
\text { Bedded } \\
\text { Tuff }\end{array}$ & $\begin{array}{l}\text { Zeolitized } \\
\text { Bedded } \\
\text { Tuff }\end{array}$ & Lava & Lava & Lava & $\begin{array}{l}\text { Zeolitized } \\
\text { Bedded Tuff }\end{array}$ & Lava & $\begin{array}{l}\text { Zeolitized } \\
\text { Bedded } \\
\text { Tuff }\end{array}$ & $\begin{array}{l}\text { Zeolitized } \\
\text { Bedded } \\
\text { Tuff }\end{array}$ & $\begin{array}{l}\text { Zeolitized } \\
\text { Bedded } \\
\text { Tuff }\end{array}$ & $\begin{array}{l}\text { Zeolitized } \\
\text { Bedded } \\
\text { Tuff }\end{array}$ & $\begin{array}{l}\text { Zeolitized } \\
\text { Nonwelded } \\
\text { Tuff }\end{array}$ \\
\hline $\begin{array}{l}\text { Announced } \\
\text { Yield (kt) }\end{array}$ & $20-150$ & $20-150$ & $20-150$ & $20-200$ & 76 & $20-150$ & $20-150$ & 1150 & $20-150$ & $20-150$ & $20-150$ & $200-1000$ \\
\hline $\begin{array}{l}\text { SDOB } \\
\left(\mathrm{m} / \mathrm{kt}^{1 / 3}\right)^{\mathrm{b}}\end{array}$ & 102 & 113 & 114 & 104 & 149 & 128 & 103 & 134 & 103 & 103 & 106 & 122 \\
\hline $\begin{array}{l}\text { Release } \\
\text { Detected }^{c}\end{array}$ & No & $\begin{array}{l}\text { Onsite } \\
\text { only }\end{array}$ & $\begin{array}{l}\text { Onsite } \\
\text { only }\end{array}$ & No & Onsite only & Onsite only & No & No & No & No & No & No \\
\hline Species $^{c}$ & & $\mathrm{I}, \mathrm{Xe}$ & $\begin{array}{l}\mathrm{Xe}, \mathrm{H}, \mathrm{Kr}, \\
\text { I, tritiated } \\
\text { water }\end{array}$ & & $\mathrm{Xe}$ & $\mathrm{H}, \mathrm{Kr}$ & & & & & & \\
\hline Comments $^{\mathrm{c}}$ & & $\begin{array}{l}\text { Drillback } \\
\text { release } \\
\text { from the } \\
\text { drilling } \\
\text { platform }\end{array}$ & $\begin{array}{l}\text { Drillback } \\
\text { releases } \\
\text { from the } \\
\text { postshot } \\
\text { ventilation } \\
\text { line }\end{array}$ & & $\begin{array}{l}\text { Drillback } \\
\text { release from } \\
\text { the ventilation } \\
\text { system }\end{array}$ & $\begin{array}{l}\text { A controlled } \\
\text { gas } \\
\text { sampling } \\
\text { containment } \\
\text { tank release }\end{array}$ & & & & & & \\
\hline
\end{tabular}

a USDOE, 2000

${ }^{\mathrm{b}}$ Assuming the maximum of the announced yield range in USDOE (2000)

'USDOE, 1996 


\section{References}

Bechtel Nevada, 2002, A Hydrostratigraphic Model and Alternatives for the Groundwater Flow and Contaminant Transport Model of Correction Action Units 101 and 102: Central and Western Pahute Mesa, Nye County, Nevada, Bechtel Nevada, Las Vegas, Nevada, DOE/NV/11718-706.

Clark, S. and G. Pawloski, 1985, U20aq Preliminary Site Characteristics Summary, Lawrence Livermore National Laboratory, Livermore, CA, CP 85-114.

Clark, S. and G. Pawloski, 1986, U20at Site Characteristics Report, Lawrence Livermore National Laboratory, Livermore, CA, CP 86-56.

Grasso, D., 2003. GIS Surface Effects Map Archive, Nevada Test Site, Nevada, USGS OFR-03051 (searchable database at http://pubs.usgs.gov/of/2003/151/Archive/Start.htm).

Hasler, J.W., 1964, Geologic Appraisal of the U20c and U20d Sites, Pahute Mesa, Nevada Test Site, United States Department of the Interior, Geologic Survey, Federal Center, Denver, CO, Technical Letter: Special Studies-I-12.

Howard, N.L. and J.L Wagoner, 1985, U20ao Preliminary Site Characteristics Summary, Lawrence Livermore National Laboratory, Livermore, CA, CP 85-74.

Howard, N.W., 1978, U20ae Preliminary Site Characteristics Summary, Lawrence Livermore National Laboratory, Livermore CA, DM 78-5.

Howard, N. and H.L McKague, 1975, Preliminary Site Characteristics Summary U20f, Lawrence Livermore National Laboratory, Livermore CA, UOPKB 75-115.

Hudson, B. and T. Stubbs, (no date), Tenabo Containment Report, Lawrence Livermore National Laboratory, Livermore, CA, UCRL-MI-106506.

McKague, L. J.Hearst, and B. McKinnis, 1989, U20bc Site Characteristics Report, Lawrence Livermore National Laboratory, Livermore CA, CP 89-48.

Newmark, R.L. and J.L. Wagoner, 1990, U20bb Site Characteristics Report, Lawrence Livermore National Laboratory, Livermore CA, CP 90-72.

Olsen, C.W., 1993, Site Selection and Containment Evaluation for LLNL Nuclear Events, Lawrence Livermore National Laboratory, Livermore CA, UCRL-JC-113334.

Orkild, P.P. and E.C. Jenkins, 1968, Preliminary Geologic Report on the U20t Emplacement Hole, Pahute Mesa, Nevada Test Site, United States Department of the Interior, Geologic Survey, Federal Center, Denver, CO, Technical Letter: Special Studies-I-64.

Pawloski, G.A., 1999, Development of Phenomenological Models of Underground Nuclear Tests on Pahute Mesa, Nevada Test Site - Benham and Tybo, Lawrence Livermore National Laboratory, Livermore, CA, UCRL-ID-136033.

Pawloski, G.A., 1985, U20ak Preliminary Site Characteristics Summary, Lawrence Livermore National Laboratory, Livermore, CA, CP 85-19. 
Evaluation of Cavity Collapse and Surface Crater Formationat the Salut Test in U20ak

Stubbs, T. and R. Heinle, 1995, Salut Containment Data Report, Lawrence Livermore National Laboratory, Livermore, CA, UCRL-ID-121263.

Tate, P., T. Stubbs, and B. Hudson, Hornitos Containment Data Report, Lawrence Livermore National Laboratory, Livermore, CA, UCRL-MI-103510.

USDOE (U.S. Department of Energy), 2000, United States Nuclear Tests July 1945 through September 1992, U.S. Department of Energy, Nevada Operations Office, Las Vegas, NV, DOE/NV-209, Rev 15.

USDOE (U.S. Department of Energy), 1996, Radiological Effluents Released from U.S. Continental Tests 1961 through 1992, U.S. Department of Energy, Nevada Operations Office, Las Vegas, NV, DOE/NV-317, Rev 1.

Wagoner, J.L., 1984, U20al Preliminary Site Characteristics Summary, Lawrence Livermore National Laboratory, Livermore, CA, CP 84-49. 